\title{
Review on Siddha Drug: Panchalavana Parpam
}

\author{
Rekha V ${ }^{1}$, Essakky Pandian $G^{2}$ \\ ${ }^{1}$ PG Scholar, Department of Gunapadam, ${ }^{2}$ Reader, Department of Gunapadam, \\ Government Siddha Medical College, Palayamkottai, Tirunelveli, Tamil Nadu, India. \\ Corresponding Author: Rekha V
}

\begin{abstract}
In Siddha system, medicine includes the herbal products, inorganic substances and animal products that lead to different formulations ranging from low shelf life drug to high shelf life drug. Parpam is the powdered substance generally obtained by calcification of purified metals, minerals and animal products by specific process. The current review aims to explore about Siddha formulation "Panchalavana Parpam" for the management of Kiraani and associated symptom. The details about the Siddha formulation "Panchalavana Parpam" was acquired from Siddha text Boghar 700: Pg. No: 49 and the details of each ingredients of above drug were collected from various Siddha texts. According to the results, all five ingredient of this preparation having the potency of relieving Soolai, Kiraani, gunmam, like gastero intestinal tract diseases. This preliminary literature review related research provides useful documentary evidences for medicinal ingredients those are commonly using to prepare the medicine for health management.
\end{abstract}

Key Words: Panchalavana Parpam, gunmam, Kiraani Siddha system

\section{INTRODUCTION}

Diarrhoeal disease is the second leading cause of death in children under 5 years old. It is both preventable and treatable. According to WHO $13.2 \%$ of all childhood deaths were caused by Diarrhoea and the worldwide prevalence of chronic diarrhea ranges from 3 to $20 \%$. Each year diarrhoea kills around 525,000 children under 5years. Globally, there are nearly 1.7 billion cases of childhood diarrhoeal disease every year. About 1.7 to 5 billion cases of diarrhea occur per year. It is most common in developing countries, where young children get diarrhea on average three times a year. Total deaths from diarrhea are estimated at 1.26 million in 2013-down from 2.58 million in 1990. In 2012, it was the second most common cause of deaths in children younger than five $(0.76$ million or $11 \%)$. Frequent episodes of diarrhea are also a common cause of malnutrition and the most common cause in those younger than five years of age Prevalence of diarrhea is highly heterogeneous across the states of India, and it ranges from $0.1-33.8 \%$ in period $2007-2008$ and $0.6-29.1 \%$ in period 2015-2016.

Diarrhoea is defined as the passage of more than 200gm of stool daily, and measurement of stool volume is helpful in confirming this. The most severe symptom in many patients is urgency of defecation and faecal incontinence is a common event.

It may be divided into 2 types.

1. Acute diarrhoea

2. Chronic (or) Relapsing diarrhoea

Acute diarrhoea is extremely common and is usually due to faecal -oral transmission of bacteria or their toxins. Chronic diarrhoea is increased frequency of defecation and loose, watery pellet stools, diarrhea that lasts for more than 2-4 weeks considered persistent or chronic. Chronic diarrhoea can be catogorised as disease of the colon or small bowl or malabsorption. 
Chronic diarrhoea is classified into three types,

Chronic watery diarrhoea

Chronic Inflammatory diarrhoea

Chronic diarrhoea with steatorrhoea

According to the Siddha Literatures Kiraani is Co-Related to chronic diarrhoea. Abundant availability of extensive range of drugs to relieve the diseases. But there is a need of prompt effective and harmless remedies through scientific validation.

Many preventive measures and treatment methods have been described in Siddha Literature, The current review aims to explore about "Panchalavana Parpam" Siddha formulation for the management of Kiraani and associated symptom.

In siddha system, Medicine (Marundhu) is classified into two major types. They are Internal medicine (Aga Marundhu) and external medicine (Pura Marundhu). There are thirty-two internal medicine and thirty-two external medicines. Siddha medicine includes the herbal products, inorganic substances and animal products that lead to different formulations ranging from low shelf life drug to high shelf life drug. Parpams are the powder substances generally obtained by calcification of purified metals, minerals and animal products by specific process. Generally these methods of preparation of Siddha medicine involves conversion of minerals or metals into oxide or sulphide form by various herbal treatment followed by repeated high temperature calcinations and grinding cycles. Parpam thus obtained constitute ultra-small particles and are taken along with vehicles such as milk, ghee, butter, honey etc according to disease.

\section{MATERIALS AND METHODS}

The details about the Siddha formulation "Panchalavana Parpam" was acquired from Siddha text Boghar 700: Pg. No: 49 and the details of each ingredients of above drug were collected from various Siddha texts.

2.1. Purification of ingredients and of Preparation of "Panchalavana Parpam"
Kariuppu ( $\left.\mathbf{N a C l}_{2}\right)$ : Common salt dissolve in sea water or rain water is filtered and boiled in a clay pot, till it reaches semisolid state. Then it is dried in sunlight till it attains the solid states as purified salt.

Indhuppu ( $\mathbf{N a C l} \mathbf{l}_{2}$ ): Indhuppu was purified by soaking in the kaadi neer for 3 days and then exposing it to the sunlight to dry.

Valaiyaluppu (Sandevere Glass Salt): The salt is diluted into Kaadi neer and then exposed to sun light to be dried.

Kalluppu (Crystal Salt): The salt is purified by keeping It soaked in Kaadi neer and then exposing it to the sun light to be dried.

Vediuppu $\left(\mathrm{KNO}_{3}\right)$ : One part of powdered Vediuppu was mixed with two parts weight extract of the tuber of Musa paradisiaca and kept undisturbed. Then clear upper portion was taken and heated in a iron pan. Once the water contents got evaporated the sediments were kept for condensation in a copper pan. Likewise 2 part extract of tuber of Musa paradisiaca was added to the same Vediuppu and heated again. The process was repeated for 5-7 times.

\section{Methods of preparation:}

The purified salts are placed in a stone mortar and triturated. Then add juice of Cissus quadrangularis grind it for 1 saamam (3hours) this process is repeated by adding juice of Moringa oleifera, juice of Acalypha indica, juice of Vitex negundo and juice of Aloe barbadensis one by one. Then it is made into small cakes (villaigal) and dried. Then the cakes are placed within identical earthen plates and covered with cotton clay cloth (7 layers) and subjected into incineration process by using cow dung cakes. After cooling calcinated cakes are taken and powdered well and then preserved in an airtight container.

Drugs dosage: Twice a day, 1 Kazhanju (5.1 gms)

Adjuvant: Honey

Indication of Medicine: Vaatham 80, Kudaichal, Soolai, Kaduppu, Megam, Satthi, Gunmam, Kiraani, Ruthra Vaayu, Kudal purattal, Mantham, Magotharam 


\section{RESULTS AND DISCUSSION}

\begin{tabular}{|c|c|c|c|c|}
\hline S.No & Tamil name & English name & Chemical name /Botanical name /Zoological name & Quantity \\
\hline 1. & Valaiyaluppu & Sandevere glass salt & Sodium silicate & 1 palam (35 gram) \\
\hline 2. & Inthuрри & Rock salt & Sodium chloride Impura & 1 palam (35 gram) \\
\hline 3. & Vediyuppu & Salt petre & Potassium nitrate & 1 palam (35 gram) \\
\hline 4. & Kalluppu & Crystal salt & Sodium chloride & 1 palam (35 gram) \\
\hline 5. & Kariyuppu & Common salt & Sodium chloride & 1 palam (35 gram) \\
\hline
\end{tabular}

General Properties of Ingredients:

Valaiyaluppu:

"Thulaiyaar kudalvaathath thonthavaa thaththo Dilaiyaach suvasamaru minnum valaiyaluppaat Kunmavali soolaiveppang kooraappi leekamivai Senmamvid dodumenath ther"

Kudal vatham, vathapitham, Iraippu (Dyspnea), Vayitruvali (Stomach pain), Keelpidippu, Suram (Fever), Peelikam (Splenomegaly) can be cured by Valaiyaluppu.

\section{Inthuppu:}

"Attakunma mantham asirkaranchsoor seethapiththanth Thuddavaiyam naadippun dodankal - keddamalak Kadduvida vinthaiyak kaamiyanoi vankarappan Vidduvida vinthuppai vizh."

Eight types of gunmam (Stomach pain), mantham, asirkaram (Stomatitis), naadippun (varicose ulcer), visam and kaamiyanoi (venereal diseases) can be cured by Inthuppu.

\section{Vediyuppu:}

"Mallaaru mattakunma maatharutha rakkaddi Kallaa mathaippuneerk kaddaruka - lellaamea Kampikampi yentrung karuvundaa mankinintra Kampikampi yentruraikkung kaal."
Eight types of Gunmam (Stomach pain), karuppaayasakaddi (uterine tumour), sopai (Aneamia), neersurukku (dysuria) are cured by Vediyuppu.

\section{Kalluppu:}

"Iyamarunch soolai yarosipiththnch saththiyodu Veyyapini yattagunmam viddekum - peyvalaiye Vaathamathi thaakam malakkaddum pomulakit Kotharukal luppaik kodu."

Soolai (pain), kapham (phlegm), kuththal, arusi (ageusia), vaanthi (vomiting), eight types of gunmam (Stomach pain), vatham, naavaratchchi (dryness of tongue) and malapantham (constipation) are cured by Kalluppu.

\section{Kariyuppu:}

"Azhaththilurai nallup panal vaatham maatrung Kalaththunoi thannaik kazhaiyung - kizhaiththakapa Aasudaiya vallainoi ashtagunma mumpokkung Kaasiniyul maathe kazharu"

Piththavatham, kandakkazhalai (cervical lymphadenopathy), kapam, kalleeral noi (liver diseases), eight types of gunmam are cured by Kariyuppu.

According to the general character of ingredients, all five ingredients are useful to treat the gunmam.

Table 1: Details of ingredients of Panchalavana Patpam

\begin{tabular}{|c|c|c|c|c|c|}
\hline Tamil Name & Other Names & $\begin{array}{l}\text { Chemical } \\
\text { Name }\end{array}$ & $\begin{array}{l}\text { English } \\
\text { Name }\end{array}$ & $\begin{array}{l}\text { Pharmacological } \\
\text { actions }\end{array}$ & Indications \\
\hline Kariyuppu & $\begin{array}{l}\text { Sotruppu, } \quad \text { Kadaluppu, } \\
\text { Veettuppu, } \quad \text { Ilavanam, } \\
\text { Samuthra lavanam }\end{array}$ & $\begin{array}{l}\text { Sodium } \\
\text { Chloride }\end{array}$ & $\begin{array}{l}\text { Common } \\
\text { salt, Table } \\
\text { salt }\end{array}$ & $\begin{array}{l}\text { Stomachic, emetic, } \\
\text { anthelmintic, laxative, } \\
\text { febrifuge, anti ulcer }\end{array}$ & $\begin{array}{l}\text { Pithavatham, lymphadenitis, } \\
\text { tumour, kapham, liver disorders, } \\
\text { eight types of gastric ulcers, } \\
\text { indigestion, distended abdomen, } \\
\text { vayu and the retention of urine } \\
\text { will be cured. }\end{array}$ \\
\hline Kalluppu & Kadat kuruvi & $\begin{array}{l}\text { Sodium } \\
\text { chloride }\end{array}$ & $\begin{array}{l}\text { Crystal } \\
\text { salt }\end{array}$ & $\begin{array}{l}\text { Emetic, laxative, } \\
\text { analgesic, anti ulcer }\end{array}$ & $\begin{array}{l}\text { Kapham, pricking pain, loss of } \\
\text { taste, pitha, vomiting, eight types } \\
\text { of gastric ulcer, vatha disease, } \\
\text { dryness of tongue, constipation }\end{array}$ \\
\hline
\end{tabular}




\begin{tabular}{|c|c|c|c|c|c|}
\hline \multicolumn{6}{|c|}{ Table 1 continued... } \\
\hline Inthuppu & $\begin{array}{l}\text { Cynthavam, chindooram, } \\
\text { chandiranuppu, } \\
\text { mathikoormai, } \\
\text { mathiuppu, minthachol }\end{array}$ & $\begin{array}{l}\text { Sodium } \\
\text { chloride } \\
\text { Impura }\end{array}$ & Rock salt & $\begin{array}{l}\text { Laxative, carminative, } \\
\text { diuretic, anti ulcer, } \\
\text { stomachic }\end{array}$ & $\begin{array}{l}\text { Eight types of gastric ulcer, } \\
\text { indigestion, blood diseases, } \\
\text { kaphapitham, kapathikkam, } \\
\text { constipation, nerve syphilis, } \\
\text { vagina diseases, cataract, asthma, } \\
\text { hemorrhoids, polydipsia, rat bite, } \\
\text { vatha pain, throbbing pain }\end{array}$ \\
\hline Vediyuppu & $\begin{array}{l}\text { Pottiluppu, Inangan, } \\
\text { padairasan, } \\
\text { Boomikoormai, } \\
\text { navacharamithru }\end{array}$ & $\begin{array}{l}\text { Pottasium } \\
\text { nitrate }\end{array}$ & Salt petre & $\begin{array}{l}\text { Demulcent, diuretic, } \\
\text { diaphoretic, anti ulcer }\end{array}$ & $\begin{array}{l}\text { Eight types og gunmam, uterus } \\
\text { fibroids, anorexia, anaemia, } \\
\text { urinary tract infection, ascites, } \\
\text { abdominal distension, asthma, eye } \\
\text { disease, rhematic disorders, } \\
\text { gonorrhoea }\end{array}$ \\
\hline Valaiyaluppu & Madavaarkaraththuppu & $\begin{array}{l}\text { Sodium } \\
\text { silicate }\end{array}$ & $\begin{array}{l}\text { Sandevere } \\
\text { Glass salt }\end{array}$ & $\begin{array}{l}\text { Anti inflammatory, anti } \\
\text { ulcer, anti pyretic, } \\
\text { analgesics }\end{array}$ & $\begin{array}{l}\text { Enteritis, hernia, vathapitham, } \\
\text { wheezing, abdominal pain, } \\
\text { arthritis, Splenomegaly, fever }\end{array}$ \\
\hline
\end{tabular}

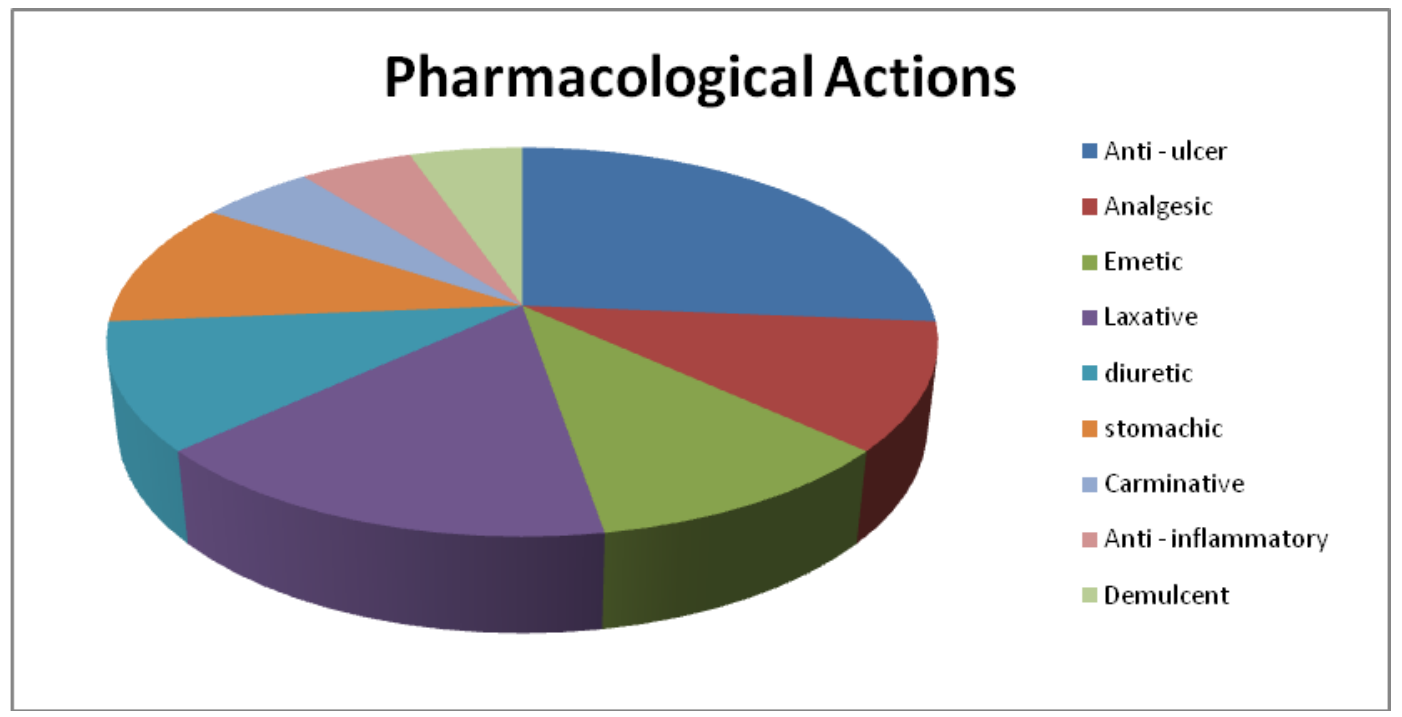

Pharmacological actions of Stomachic (02), Carminative, Anti ingredients were; Anti - ulcer (05), Laxative (03), Analgesic, Emetic, Diuretic,

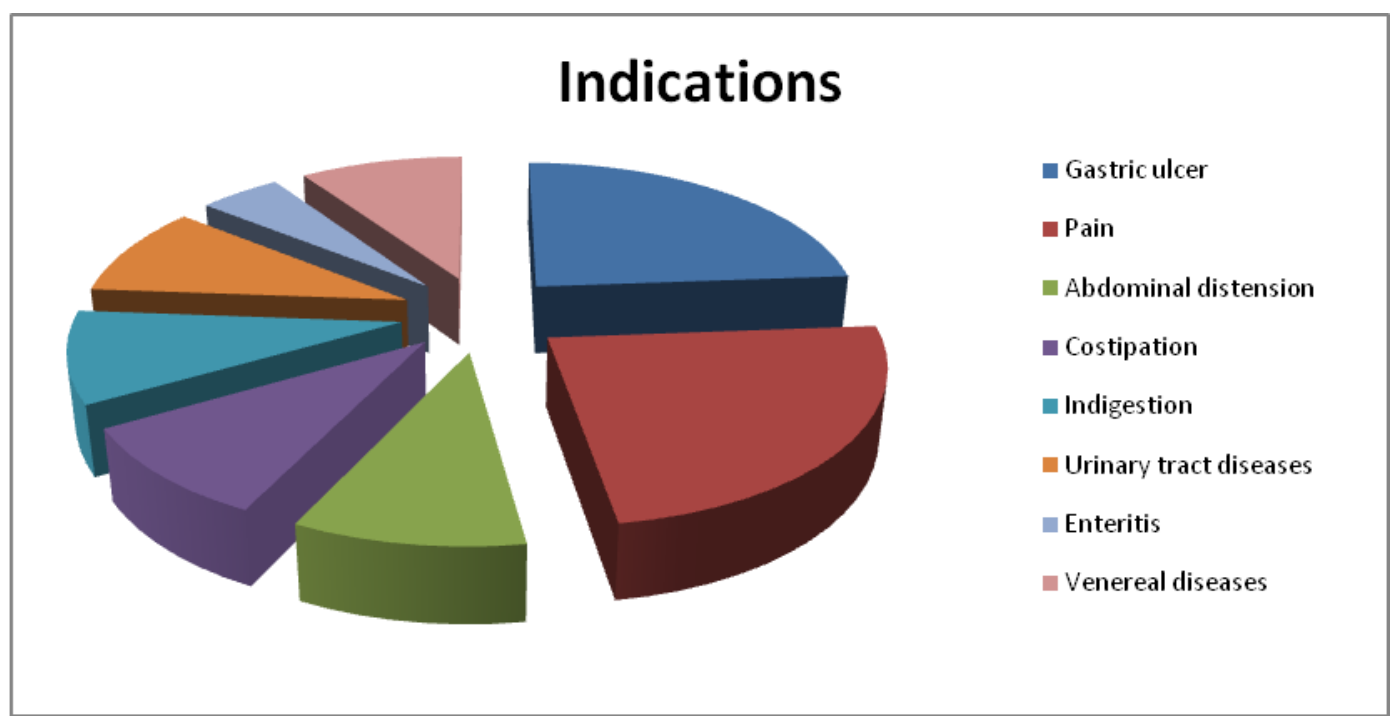

Based on the Indications of each ingredient, all five salts can be cure the gastric ulcer (eight types of gunmam) and pain and abdominal distension, constipation, Indigestion, Urinary tract diseases, venereal diseases (02), Enteritis (01) 


\section{CONCLUSION}

Panchalavana Parpam is a Siddha formulation and used to treat a wide variety of gastro intestinal tract conditions such as Kiraani, Gunmam and Soolai etc in Siddha Medicine. This preliminary literature review revealed that the pharmacological actions and indications of each ingredients of drug were matched with the indications of Panchalavana Patpam. Further extensive scientific studies also should be carried out to justify in future.

\section{Acknowledgement: None}

\section{Conflict of Interest: None}

\section{Source of Funding: None}

\section{REFERENCES}

1. K.S. Murugesa Muthaliyar, Gunapadam Mooligai vaguppu (part-I), Indian medicine - Homeopathy department, chennai-106

2. Kosaee Anupoga Vaithiya bramma Ragasiam, part-II, Thamarai noolagam, Chennai, 1999, Pg.No. 73, 172, 245.

3. Dr. R. Thiyagarajan, Gunapadam Thathu Jeeva Vaguppu - L.I.M, page no. 369- 372

4. The wealth of India - raw materials volume - II, IV, VII, VIII, IX - publications and Information directorate - New Delhi.

5. Dr.C.N. Kuppuswami , H.P.I.M Professor of Siddha College of Indian Medicine, Anubava Vaithiya Murai, pg. 99,130.

6. Dr. K.N. Kuppuswamy Mudaliyar H.P.I.M Siddha maruthuvam - pothu, 2007 edition, Indian medicine and Homeopathy department, Chennai-106.

7. Dr. K.N. Kuppusamy Muthaliar, Dr. K.S. Uthamarayan, H.P.I.M. Siddha Vaithiya Thirattu, Department of Indian Medicine and Homeopathy, Chennai, First edition 1998.

8. Thanjai Vaithiyaraja Sinthamani, Part - I, P. Boopathi Nayagar, Chennai, Pg. No. 166, 167, 34.

9. Agathiyar - 2000- Part - III, Saraswathi Mahal Noolagam, Thanjavur, Dr.S. Venkatarajan, Pg. No. 159, $160,161,162,163,164,165$.

10. T.V. Sambasivam pillai, Tamil - English Dictionary, vol-I, II, IV, V, 1994 edition, Dept. of Indian medicine and Homeopathy, Chennai - 106.

11. Dr. Anaivaari R. Anandan, Ph.D., Dr. M. Thulasimani, M.D.(Pharm)., Siddha Materia Medica (Mineral and Animal kingdom), 2008 edition, Dept. of Indian medicine and Homeopathy, Chennai - 106.

12. S.P.Ramachandran,Gunapadam kaiyedu,Thamarai noolagam,creative offset,Chennai-26.

13. R.C.Mohan,Pathartha guna cinthamani,Dec2006 Edition, Thamarai noolagam, Chennai.

14. Chikichcha Raththina Theepam ennam Vaiththiya Nool, Author Viththiya Viththuvan Mani S.Kannuchamipillai, B.Rathananayakar\& Sons , Chennai600079

15. Dr.V.Narayanaswami,Pharmacopia of Hospital of Indian medicine, 1995, $2^{\text {nd }}$ edition,Govt branch press,Madurai.

16. T.Pulliah, Medicinal plants in India VolI,2002 edition,Regency publications, New Delhi.

17. A.K.Gupta, Wealth of India,vol-IV ,Publication and Information Directorate, New delhi,1988 edition.

How to cite this article: Rekha V, Essakky Pandian G. Review on siddha drug: panchalavana parpam. Int J Health Sci Res. 2021; 11(5): 128-132. DOI: https://doi.org/ 10.52403/ijhsr.20210518 